\title{
O HOMEM DA FICHA ANTROPOMÉTRICA E DO UNIFORME PANDEMÔNIO: LIMA BARRETO E A INTERNAÇÃO DE 1914*
}

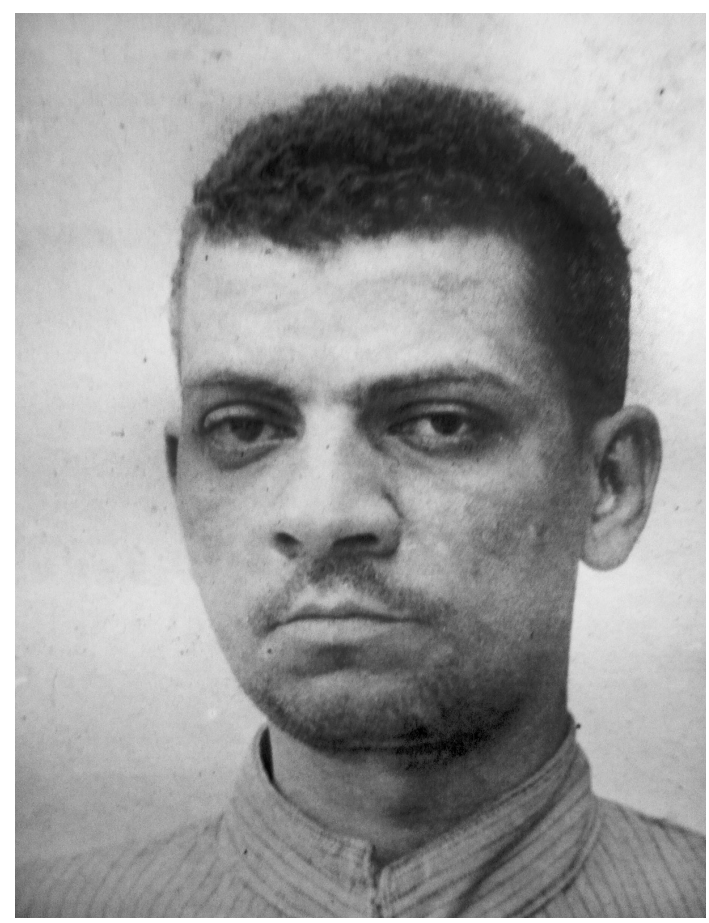

Lima Barreto, primeira internação. Acervo da Biblioteca do Instituto de Psiquiatria da UFRJ, 1914.
Nome: Affonso Henriques de Lima Barreto Idade: 33

Cor: branco

Estado civil: solteiro

Nacionalidade: brasileira

Profissão: empregado público

Entrada: 18-08-14

Diagnóstico: alcoolismo

Tratamento: purgativo, ópio 
Retrato em branco e negro, ficha antropométrica preenchida... É dessa maneira que Lima Barreto aparece nos registros do Hospício Nacional de Alienados do ano de 1914. A instituição remonta o ano de 1841, com o nome de Hospital Pedro II, quando José Clemente Pereira, provedor da Santa Casa de Misericórdia do Rio de Janeiro, iniciou campanha pública em favor da criação de um hospício de alienados na Corte. Era preciso separar os loucos dos demais doentes, assim como ministrar-lhes tratamento diverso, em função da natureza agora reconhecida da moléstia. Não que a doença fosse de todo desconhecida. No Código de Posturas Municipais do Império, os loucos e os embriagados eram associados a animais ferozes, e representavam perigo social. Também o relatório de Salubridade da Sociedade de Medicina de 1839 entendia a loucura como uma doença especial, mas, como não havia um hospício na Corte, e apenas poucos hospitais pertencentes a irmandades religiosas recebiam alienados, restava aos médicos alertar sobre alcances da moléstia. Assim, doentes internados nesses locais ou no Hospital da Santa Casa da Misericórdia, permaneciam em cubículos mal-iluminados e ventilados, e, superada a crise, eram logo restituídos às famílias (Engel, 2001: 194-195).

A necessidade de uma instituição desse tipo era justificada não só por conta da especificidade da moléstia e da falta de condições para tratá-la de maneira adequada, como em nome dos próprios doentes. Pautados nos modelos de Pinel, Esquirol, Frank, Dubois, entre outros, nossos médicos preconizavam o isolamento da loucura. E aprovado o projeto, foi logo selecionado pela mordomia do Império o edifício, que começou a ser construído em 1842. Em 1852, no dia da sagração de Pedro II, foi inaugurado o imponente prédio de arquitetura neoclássica, localizado em lugar de especial beleza natural. De lá se observava um espetáculo natural pungente: a baía de Botafogo, a Serra dos Órgãos, as montanhas de Niterói, o Pão de Açúcar e a Urca. ${ }^{1}$ Estranho paradoxo opunha a paisagem natural de fora à paisagem humana de dentro: internos anônimos, vagando maltrapilhos e unidos apenas por uma etiqueta comum: a loucura. Anos depois, a arquitetura do hospital seria questionada, uma vez que, segundo a concepções vigentes - pautadas numa ciência asséptica - não era de bom tom tamanha demonstração expressa em construção tão suntuosa. Grande arquitetos, como Domingos Monteiro, José Maria Jacinto Rebelo e Joaquim Cândido Guilhobel foram chamados para implementar o edifício, atestando a relevância do projeto nos planos do Império, cuja política científica voltava-se fortemente para a aplicação das novas ciências e tecnologias; símbolos da civilização e do progresso. A princípio o muro do hospital era totalmente devassado, expondo demais o cotidiano dos pacientes, já que o local era ponto frequente de visitação dominical. A partir de 1855, porém, um gradil passou a separar os loucos do restante da sociedade. Não por acaso Lima Barreto, em seus diários, descreveria o hospício como "frio, severo, solene, com pouco movimento nas massas arquiteturais" (Barreto, 2010c: 214). 
Temas como loucura andavam em voga, e, sobretudo num país mestiçado, não eram poucos os teóricos que defendiam teses sobre a maior incidência de casos numa nação de raças em desequilíbrio. ${ }^{2}$ Com a chegada dos primeiros pacientes ao Hospício Pedro II, transferidos em sua maior parte da Santa Casa da Misericórdia, o cotidiano passa a se estruturar. A organização da construção separava, em primeiro lugar, os homens (que ficavam na ala esquerda), das mulheres (na direita). Além do mais, os alienados eram divididos a partir de sua origem social: aqueles admitidos gratuitamente (indigentes, escravos e marinheiros) e os pensionistas (discriminados como "primeira classe", com tratamento especial, e "segunda classe", com direito a quarto para dois internos). Os alienados eram também diferenciados pelo comportamento: tranquilos, agitados, imundos, afetados por moléstias acidentais ou crônicas. Bastante simples, a classificação combinava critérios que atentavam para a condição social, a higiene, a incidência de outras moléstias, a manifestação da loucura e seu grau de periculosidade.

O hospício tinha como objetivo a cura, mas suas possibilidades eram limitadas, uma vez que faltavam médicos, enfermeiros e remédios. Em primeiro lugar, não existia distinção clara entre punição e tratamento. De maneira indiscriminada, ministravam-se banhos como tratamento, mas também para controle de pacientes "nervosos". De forma também alargada, empregavam-se substâncias farmacológicas (como o ópio), sangrias e purgatórios. Além do mais, como essa era considerada uma doença moral, o trabalho cumpria função primordial. As mulheres costuravam, lavavam e engomavam roupas, enquanto os homens dedicavam-se à limpeza local, atuando como serventes nos jardins, refeitórios e enfermarias, espaços em que arrumavam camas, limpavam, varriam e lustravam os assoalhos.

O importante é que, com o correr do tempo, a instituição passaria a representar um dos orgulhos do modelo civilizatório praticado pelo Império brasileiro, afeito a todo tipo de novidade que prometesse a elevação moral. Entretanto, com a chegada da República, não apenas o regime iria mudar, como procedeu-se a uma alteração acelerada de nomes, títulos e emblemas. E o "Pedro II" não ficaria atrás: logo em janeiro de 1890 seria rebatizado como Hospício Nacional de Alienados e, em 1911, Hospital Nacional de Alienados.

Por outro lado, nesse contexto, novos modelos entravam em voga, sobretudo a "teoria da degenerescência" elaborada por Morel e difundida por Magna, e a do "organicismo", que estabelecia a predominância dos elementos biológicos aos sociais. Eles levariam a uma mudança de enfoque com relação à loucura e à importância das determinações hereditárias. A essas novas conclusões correspondiam novas terapêuticas, uma medicalização crescente e um aprimoramento desse tipo de instituição asilar. Críticas ao hospital abundavam e nomeavam desde o caráter inapropriado de sua arquitetura, até a falta de médicos ou a superlotação. E as mudanças logo se inscreveriam numa nova 
estrutura. Em 1890 é criada a Assistência Médica e Legal dos Alienados, que administraria o Hospício Nacional de Alienados e as colônias de Alienados da Ilha do Governador (Mesquita e São Bento). O hospício passa, pois, a contar com uma logística distinta e independente da Santa Casa da Misericórdia. Aumentava-se, ainda, a autoridade do médico, que teria uma espécie de tutela sobre seus pacientes, desbancando o poder familiar.

É esse tipo de estabelecimento que recebe Lima Barreto, em agosto de 1914. Ele, já escritor de certa fama, reconhecido como voz crítica e atuante, parecia, diante dessa situação, como mais uma personagem anônima qualquer, um alienado passageiro já que sujeito ao delírio do álcool. Tudo ao contrário do que era seu grande sonho: o de projetar-se como uma persona literária e um testemunho desses novos tempos. Sua história pessoal parecia repetir o que as teorias raciais da época, e os prognósticos mais negativos e deterministas, apontavam: não se escapava da raça de origem, e dos seus estigmas. Afinal, segundo as teorias da degeneração, indivíduos miscigenados carregariam "vícios" das duas raças que as formavam. Estabelecia-se uma correlação clara entre raça e doença mental, e se a loucura não tinha uma única raça, negros e mestiços estavam mais predispostos a ela, na medida em que entendidos como intelectualmente inferiores. Henrique Roxo, médico do Hospital, em pronunciamento no Segundo Congresso Médico Latino-Americano (1904), asseverava que negros e pardos deveriam ser considerados como "tipos" que não evoluíram; seriam retardatários entre nós. Segundo ele, se cada um carrega uma "tara hereditária", no caso desses grupos ela era "pesadíssima". O médico não deixava de incluir argumentos sociais, culpando a abolição "repentina", assim como o crescimento das cidades. Por isso, eles teriam maior propensão para a vadiagem, o álcool e demais distúrbios mentais.

Lima Barreto conhecia a loucura de perto; convivera com ela desde muito jovem. Seu pai, João Henriques, seria um dos primeiros desempregados da monarquia e para poder sobreviver aceitaria, em março de 1890, trabalho mal remunerado como almoxarife nas Colônias de Alienados da Ilha do Governador. Conheceu também a própria loucura do pai que a partir de 1902 mostrou os primeiros sinais e nunca mais voltou à razão. Isso fez com que Lima Barreto, filho mais velho, virasse arrimo de família, assim como que, vexado, convivesse com os urros diários do pai, na nova casa no subúrbio carioca, em que passariam a viver. ${ }^{3}$

Há extensa bibliografia sobre alienismo no XIX, e, no Brasil, uma série de especialistas vem se dedicando ao tema. ${ }^{4} \mathrm{O}$ objetivo deste pequeno artigo não é, pois, trazer novos dados sobre a prática, ou traçar um panorama acerca de sua terapêutica no Brasil. A ideia é, antes, a partir de um material delimitado, qual seja, os dados retirados dos prontuários de "observação clínica" do Hospital Nacional de Alienados realizadas no ano de 1914 - quando Lima Barreto foi internado pela primeira vez —, perceber por meio da comunicação improvável 
entre imagem (as fotos captadas na ocasião da internação, supostamente contra a vontade dos doentes) e texto (os dados anotados nas fichas pelos médicos que entrevistavam os novos pacientes), a partir dos detalhes, como poderiam ocorrer possíveis diálogos, por certo dialógicos, num asilo como esse.

São muitos os nomes e rostos "observados", hoje meros desconhecidos, cada um carregando seus dramas pessoais, descritos nos pequenos relatos que mencionam brigas, manias religiosas ou políticas, agressividade, criminalidade, fanatismo religioso, alcoolismo, ciúme e toda uma vasta gama de experiências, todas classificadas por um rótulo forte e generalizante. A loucura parece ser o contrário da ordem e da normalidade, uma corruptela para pensar em exagero, afetação, agitação, periculosidade ou, como mostra Castel, "um excesso que é falta" (Castel, 1978: 111).

O conjunto das fichas traz um universo de certa maneira recorrente: boa parte dos internados são brasileiros, sendo os estrangeiros em geral portugueses e espanhóis. Divididos por cor — brancos, pardos ou negros -, a maioria deles são classificados como brancos, a despeito das fotos traírem a objetividade das fichas, uma vez que a pele, os traços, os cabelos revelam que a maioria dos casos incide sobre uma população escura e pobre. Também se anotou, quando possível, ou quando o silêncio do paciente não escorre para as próprias fichas, a profissão do novo interno. As mulheres foram em sua totalidade definidas como "domésticas"; já os homens em sua maior parte como "trabalhadores", depois comerciantes e ainda estivadores, mecânicos, tipógrafos, pedreiros, alfaiates, serralheiros, carregadores, um "chauffeur" e dois empregados públicos; dentre eles Lima Barreto. Aí estava o que restava da identidade, ao menos provisoriamente roubada, desses cidadãos destituídos de seu direito de arbítrio.

Nas fichas de observação, a partir de pequenos detalhes, percebe-se o diálogo difícil e por certo hierarquizado entre doente e médico, no sentido de garantir, de um lado, a singularidade; de outro, deixar-se catalogar a partir de uma situação que, contra a vontade de muitos, parecia unir a todos. Ou seja, se o "diagnóstico" continha certa variação - alcoolismo, epilepsia, psicose periódica, paralisia geral, delírio episódico, demência senil, debilidade mental, esclerose cerebral, sífilis cerebral ou simplesmente psicose dos degenerados, isso quando os termos não vinham seguidos por um ponto de interrogação -, já o tratamento era bastante recorrente, resumindo-se à prescrição de purgatório, ópio ou tônicos calmantes. Por outro lado, enquanto o notário parece tentar preencher a profissão sempre de maneira pouco específica pode-se notar, em alguns casos, o esforço do interno de discriminar a profissão e assim ganhar um local diferenciado nessa instituição que tende a jogar a todos na mesma grande vala comum da loucura. Lima Barreto queria ser classificado como escritor; ficou apenas (mas pelo menos) como funcionário público. Profissão que tantas vezes ironizou, e que, durante toda a vida, considerou menos relevante do que o seu compromisso com a literatura. 
Nosso interesse, ademais, girará em torno de Lima Barreto que, em seus diários, anota a "humilhação" que sentiu ao perder sua identidade e se ver transformado num "mulato", desses que tantas vezes manifestavam a fraqueza da loucura mestiça - a "psicose dos degenerados". Pouco adiantaria, nessa hora, seu conhecimento crítico do darwinismo racial. Sobra o desânimo e a melancolia presentes nas páginas de seu diário, onde escreveria: "A capacidade mental dos negros é discutida a priori a dos brancos a posteriori. A ciência é um preconceito grego, é ideologia" (Barreto, 1998: 15).

Com o objetivo de lidar com esse material, nos valemos do método indiciário de Carlo Ginzburg, desenvolvido no livro Mitos, emblemas e sinais (1989) e no artigo "O inquisidor como antropólogo" (1998). Como mostra o historiador, muitas vezes a partir de pequenos detalhes se chega a conclusões de maior amplitude. Vale a pena também emprestar o modelo dialógico, à moda de Mikhail Bakthin (1987), e igualmente aplicado por Ginzburg, que mostra como, a despeito das posições hierarquicamente desiguais, que se estabeleciam entre (no seu caso) inquisidor e vítima, travavam-se debates dialógicos no sentido da tensão que se apresentava entre ambos, mas igualmente na compreensão de um universo cultural partilhado, por vezes silenciosamente, por vezes de maneira aberta e conflitiva. Tendo como modelo os romances de Dostoiévski, Bakthin definiu tal conceito:

não como a unidade de uma só consciência que teria absorvido, como objetos, outras consciências múltiplas, nenhuma das quais se torna completamente objeto de outra. Essa interação não permite que o observador exterior objetive todo o evento segundo o modelo monológico habitual (temático, lírico ou cognitivo) e desta maneira obrigando-o a colocar-se como participante (Bahktin, 1970: 51). ${ }^{5}$

Nem inquiridor, nem inquirido são tomados como passivos nessa relação, embora não se desconheçam as desigualdades de poder existentes entre eles.

Mais uma explicação prévia: essa não foi a única vez que Lima esteve internado e não foi, nem ao menos, um registro isolado. Vamos sim nos referir à segunda entrada do escritor no hospício, e nos depoimentos que legou, mais ao final do artigo. O corpo do texto será tomado, no entanto, pela análise dos documentos de 1914, uma vez que optamos por privilegiar uma investigação mais verticalizada, ao insistir no caderno da primeira internação. Essa foi a primeira, a mais chocante e marcante das internações, a despeito de não ter sido a mais longa. Além do mais, faremos pequena digressão acerca dos pacientes internados nesse mesmo ano, e cujas fichas estão próximas ao prontuário de Lima Barreto. O conjunto permite entender, e de maneira mais abrangente, processos de humilhação experimentados pelo literato, e certo perfil daqueles com quem o escritor foi obrigado a conviver nesse primeiro período como interno no Hospital Nacional de Alienados. 


\section{O PACIENTE LIMA BARRETO: UMA FOTO E UMA FICHA}

Hoje tive um pavor burro. Estarei indo para a loucura? (Lima Barreto, 1998, p. 89)

Aquele que entrar na Biblioteca do Instituto de Psiquiatria da Universidade Federal do Rio de Janeiro, nos fundos do campus da Praia Vermelha, uma construção de dois andares, localizada ao lado do edifício onde funciona o Instituto Psiquiátrico Philippe Pinel - no espaço onde hoje funciona o ambulatório e local de internação dos pacientes para lá encaminhados - e pedir o Livro de Observações do ano de 1914, há que se deparar com um documento encadernado, repleto por questionários com conteúdo padrão, respondidos ou em parte vazios, fotos em branco e preto, seguidas de outras descrições. A impressão causa grande impacto, tal a intimidade lá revelada, tamanha a violência a que estão expostas essas personagens cujos nomes e feições parecem ter se perdido na pátina do tempo. Mas um deles, cuja entrada se deu no dia 18 de agosto, com certeza se destaca em meio a essa massa de desconhecidos: o escritor Affonso Henriques de Lima Barreto, que tinha então 33 anos. É certo que não há como virar a página, pois hoje o conhecemos. No entanto, a foto chama atenção, igualmente, por conta do estranhamento da situação e da imagem que lá surge estampada. Portando roupas de detento, com um carimbo estampado em sua roupa - pandemônio - , o rapaz mira a câmara fotográfica, e se não fosse um certo olhar entristecido, um pouco baixo, pareceria desafiá-la. Pandemônio tem origem inglesa pandemonium, através do radical grego pân, que significa "todo", sendo acrescido o termo grego daímon, que quer dizer "demônio". Tal neologismo foi criado pelo poeta inglês John Milton (1608-1674), no seu Paradise Lost, para designar o palácio de Satã. É também o designativo para a capital imaginária do Inferno, significando o mesmo que tumulto, balbúrdia, confusão. Se non é vero... o que importa é que a imagem, acrescida do seu título é motivo de espécie. Ainda mais porque em seu livro Cemitério dos vivos, que restou inacabado, Lima desenhara uma imagem semelhante do hospício: o inferno ou o cemitério.

O fato é que Lima andara bebendo, e muito, e sua expressão talvez seja devedora de seu estado, tal como descreve em seu Diário naquele ano. De toda maneira, e de modo diferente de outros internos, não esconde o rosto ou vira-o de lado, evitando o olhar; nem ao menos usa de qualquer subterfúgio, como tapar o rosto com as mãos, ou com outro objeto. Está lá, de corpo inteiro, diferente da imagem do dândi em começos do século ou do ativista literário, que frequentava o Café Papagaio e questionava a "panelinha literária" da Academia Brasileira de Letras, ou mesmo do escritor engajado, que atuara na acirrada campanha eleitoral para a presidência entre 1909-10.

Sua fama já lhe trouxera certos lucros e dividendos, e Lima fora contratado em 1914 para escrever uma crônica diária para o Correio da Noite, assim 
como manteria a coluna mesmo após sua estada no hospício. Também colaborava com a Gazeta da Tarde desde 1912, onde publicara uma série de relatos folhetinescos e a sátira política "Numa e a Ninfa", que depois seria convertida em romance. Publicara, ainda, dois fascículos das "Aventuras de dr. Bogoloff".

Mas foi a edição de Recordações do escrivão Isaías Caminha, em 1909, que lhe conferiu notoriedade, assim como - e na mesma medida - lhe custou caro, por conta das críticas que fazia ao racismo vigente no país e, sobretudo, das denúncias ao lobby da imprensa: segundo ele, o "4o poder da República". Em Isaías Caminha, o escritor tratava dos bastidores do jornal Correio da Manhã (trocando o nome do periódico para Globo) e, sem um pingo de ingenuidade, afirmara na ocasião: "Eu não tenho inimigos, mas meu livro os terá". O romance havia sido publicado sob a forma de folhetim nos quatro únicos números da Floreal (1907), revista na qual Lima atuava como um dos proprietários e principal editor. Nela, o grupo composto pelos amigos e colegas de redação - Antonio Noronha Santos, Domingos Ribeiro Filho e Mário Tibúrcio Gomes Carneiro - anunciava a formação de nova geração de escritores; avessa aos formalismos da literatura vigente.

Lima Barreto também teria tempo de publicar sob a forma de folhetim outro romance satírico. Triste fim de Policarpo Quaresma foi lançado, pela primeira vez, na edição vespertina do Jornal do Comércio, e durante dois meses: de 11 de agosto a 19 de outubro de 1911, estando a história completa após 52 folhetins. Editado no jornal mais tradicional da época, Triste fim retornava aos tempos de Floriano e da Revolta da Armada, e ressuscitava os dias vividos na Ilha do Governador, quando seu pai, atuando na administração da colônia de alienados, viu sua propriedade ser invadida por revoltosos. Como vimos, a loucura se manifestaria apenas em 1902, quando o pai, à semelhança do escândalo que ocorrera com o almoxarife do Hospital de Alienados, ficou com medo de ter suas contas contestadas.

Já Lima traduziria o ambiente imperante em seu contexto, recuando, porém, aos idos de 1893, momento em que começa a Revolta da Armada. O período não lhe poderia ser mais significativo. Foi em 1890 que João Henriques foi demitido da imprensa nacional e que, por ingerências de seu antigo padrinho, Ouro Preto, acabou indo trabalhar nas Colônias de Alienados da Ilha do Governador. No ano seguinte, diante do ambiente conturbado, Deodoro da Fonseca fecha o Congresso Nacional e, frente à intensa pressão política, pede demissão. Floriano Peixoto, em contragolpe, assume o poder, com o objetivo de reconstituir a ordem constitucional. Nesse meio tempo, Lima Barreto é matriculado como aluno interno no Liceu Popular Niteroiense, passando a visitar a família apenas nos finais de semana. Nota, porém, a agitação que resultaria na Revolta da Armada, assim como percebe o desconforto do pai que se queixa, constantemente, da presença de revoltosos no local: 
Sr. Dr. Araujo. A minha posição é horrível não sei o que fazer. Vou retirar os alienados e empregados para S. Bento, e me esconder porque eles querem me pegar ou ao Sr. Não posso ir para a Cidade com minha família pois não conto [com] recursos. Agora não é mais possível trazer gêneros para aqui pois é o mesmo que entregar a eles. O que há de ser de mim! Vou para o mato assim que os avistar. ${ }^{6}$

O movimento seria contido em março de 1894; Prudente de Morais assumiria a presidência da República em novembro, em meio a clima tenso e com a promessa de reorganizar o país - em especial a capital. Lima, por sua vez, passa a estudar no Ginásio Nacional (antigo colégio Pedro II) e, após concluir a instrução primária, ingressa na Politécnica em 1907. O estudante não concluiria, porém, seus estudos, uma vez que o pai enlouquece; Lima é obrigado a trazê-lo de volta ao Rio, sair da faculdade e ingressar como amanuense na Secretaria da Guerra.

Mas por que recuar à Revolta da Armada e recuperar o tema da loucura? Veremos que na obra do autor a revolução assume papel quase simbólico, uma vez que significa a entrada na vida adulta. Lima não conclui que daí viria a demência paterna, mas já a anuncia. Assim como a morada onde a família Lima Barreto moraria a partir de 1913, em Todos os Santos, na rua Major Mascarenhas, número 42, ficaria conhecida como a "casa do louco".

Mas o alvo de Lima é, sobretudo, o seu tempo presente, e as práticas autoritárias de combate às manifestações mais populares. ${ }^{7}$ Ficaram famosas as fotografias do escritor, apresentando atitude muito desafiadora no julgamento do assassinato de três estudantes, em 1910. Com o objetivo de protestar contra a atitude dos soldados do governo, estudantes recorreram ao general Sousa Aguiar, que não os atendeu e acabou merecendo um "enterro simbólico". Diante do ato, militares intervêm nas ruas e repelem as manifestações, fazendo dois mortos. O evento comoveu a capital e Lima Barreto propôs, então, um combate público à candidatura de Hermes da Fonseca. Ruy Barbosa é, porém, derrotado nas urnas, em março de 1910, e Hermes da Fonseca eleito presidente, em clima de tensão. A frustração diante do resultado da eleição não abafa o clamor público por maior participação e em setembro daquele ano é marcado o julgamento dos responsáveis pelas mortes dos estudantes. Lima Barreto fez parte do júri, secretariou o Conselho e redigiu a sentença que condenou o tenente Wanderley e seus soldados. Isso tudo diante das pressões que sofria dentro do Ministério da Guerra - local de seu trabalho como amanuense - e que pagava os salários dos advogados dos militares.

O contexto é marcado, assim, por sentimentos mistos, que vão da desilusão à esperança num mundo mais justo e solidário. No seu caderno de anotações, ao lado do esquema para Triste fim, o escritor escreveu: "Policarpo Quaresma, ideia que mata; a decepção; o pessimismo". 
Lima Barreto. Foto tirada do livro Recordações do Escrivão Isaías Caminha, Rio de Janeiro: Brasiliense, 1956.

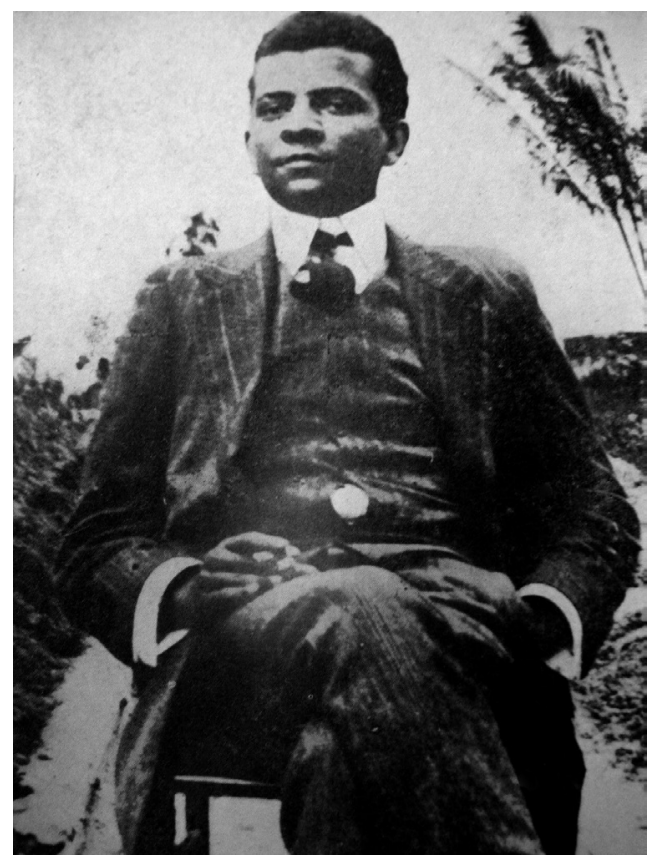

Por outro lado, se o próprio Lima, até a ocasião do livro, ainda não apresentara maiores problemas de saúde, o álcool já havia entrado em sua vida, assim como pedira e obtivera licença médica na Secretária da Guerra, no mesmo ano de 1912. Talvez por isso a loucura paire solta em Triste fim. A pobre Ismênia diante da fuga do noivo cairá demente, e Policarpo será internado durante alguns meses, já que sua atuação extremada a favor da imposição do Tupi é considerada ato insano. A loucura também está presente no quartel de Floriano, ou na impossibilidade do sítio do Sossego vingar. Por outro lado, nos diários da época, a tristeza diante desse cenário é uma constante: "A minha vida de família tem sido uma atroz desgraça" (Barreto, 1998: 55).

Não é hora de refazer a biografia de Lima Barreto: nosso objetivo é apenas enfatizar como o escritor, no ano de 1914, não era personagem desconhecida. Ao contrário, começava a aparecer de maneira mais frequente nos jornais cariocas, já havia publicado um livro escandaloso, editado folhetins em periódicos, feito suas experiências como proprietário da Floreal e atuava na cena pública carioca como uma espécie de enfant terrible. Mesmo assim, não conseguiu deixar na sua ficha a classificação que mais lhe agradava e que em seu entender o definia; escritor. Em seus diários desabafaria: "Ah literatura ou me mata ou me dá o que peço dela" (Barreto, 1993: 24).

No seu prontuário, além da discriminação da profissão, causa estranheza a "cor". Na ficha, contrariando o que a imagem evidencia, Lima Barreto é "branco". Já na fotografia, por detrás das olheiras profundas, do ar altivo, dos 
olhos desviantes, se destaca sua cor amorenada e o cabelo pixaim. Aí está essa maneira nacional de agenciar a cor, e hoje será difícil saber quem a atribuiu nesse momento: se o funcionário zeloso em "branquear" a todos, ou o próprio escritor que em sua literatura sempre destacou o fato de ser negro. Pretendia escrever uma história da escravidão, que nos diários chamou de um "Germinal negro", além de, em seus romances e contos - sobretudo Recordações do escriuão Isaías Caminha ou Clara dos Anjos - , denunciar práticas de racismo e preconceito. Nos diários desabafou: "É triste não ser branco" (Barreto, 1998: 85). Quem sabe tenha sido o notário a cometer tal "bondade", uma vez que são muitos os casos de pacientes descritos como brancos, mas evidentemente desditos pelas fotos que os estampam negros. Quem sabe tenha sido o próprio Lima que, no afã de sair daquele local o mais breve possível, recorreu ao subterfúgio da cor, até porque sabemos que internos brancos têm mais chances de ver comutada ou diminuída sua pena.

Vale a pena recorrer, também, à detalhada "inspeção geral", constante do livro de "observações clínicas" do Instituto de Psiquiatria da Universidade do Brasil. ${ }^{8}$ Nela, estabelece-se novo diálogo entre Lima e o funcionário. $\mathrm{Na}$ primeira parte do laudo, o diagnóstico é claro e não permite prever qualquer debate: "O nosso observado é um indivíduo de boa estatura, de compleição forte, apresentando estigmas de degeneração física. Dentes maus; língua com acentuados tremores fribilares, assim como nas extremidades digitais". De imediato, chamam atenção duas palavras fortes no vocabulário da época: "estigmas de degeneração”. Estigma é termo que vem da terminologia da antropologia criminal de Lombroso, muito aplicada pelos médicos locais que, à semelhança da Escola Tropical Baiana, cujo líder já falecido era Nina Rodrigues, estudava as associações entre as raças mestiças com a criminalidade e a loucura. Estigma supõe a existência de traços rígidos, fixos e essenciais, vinculados às raças, também entendidas como fenômenos naturais e finais. Supõe ainda a ação da hereditariedade como fator determinante no comportamento populacional. Pior era, não obstante, a situação das "raças mistas", essas sim sujeitas a todo tipo de degeneração. Portanto, se Lima era branco na cor, poderia ser não tão branco no diagnóstico.

O procedimento seguia a orientação do hospital e também do professor Henrique Roxo, que em 1901 defendeu a tese Duração dos atos psíquicos elementares nos alienados. Roxo substituiu seu orientador, Teixeira Brandão, na direção do Pavilhão de Observação do Hospital Nacional de Alienados e criou nova técnica para exame de "suspeitos de alienação". Segundo o médico, o questionário não deveria ser fixo, uma vez que responderia à especificidade de cada caso clínico, mas necessitaria de um método comum. O funcionário anotaria os dados físicos do paciente - sua estatura e aparência - definiria a fisionomia e por fim seu estado geral (calmo, agitado, triste, alegre, concentrado, disperso) a partir da maneira como respondia às perguntas. Essa primeira fase 
seria fundamental para definir traços degenerativos ou sinais de alienação. De lado a lado, as respostas e perguntas nada tinham de ingênuas. A etapa seguinte era mais objetiva e visava os dados antropométricos (crânio, face, orelhas, nariz, olhos, cavidade bucal). Objetos de atenção eram também os órgãos genitais, o fígado, o coração, o estômago e os intestinos. Por fim, vinha uma etapa considerada mais "subjetiva", pois visava os dados anamnésticos, ou seja as condições de vida do paciente. Nesse caso, Roxo recomendava ser necessário captar a simpatia do paciente e "deixá-lo falar" (Engels, 2001: 45).

Em suma, o objetivo era anotar cuidadosamente a fisionomia do paciente - considerada a janela do caráter —, o temperamento, o formato, as medidas do crânio e formas de expressão (mutismo ou fala abundante). Anotavam-se também as tendências intelectuais e emotivas dos doentes, sendo o excesso sempre considerado sinal de loucura. Excesso religioso era logo definido como fanatismo; assim como pendores elevados pela política e em especial para o anarquismo eram igualmente estigmas operantes. Chamados de "loucos morais", anarquistas eram condenados por sua ideias e classificados como doentes. O professor Álvaro Fernandes, da Faculdade de Medicina do Rio de Janeiro, mostrava em 1898 como o anarquista era o tipo de louco moral por excelência, "nascendo da luta social, da desarmonia entre o capital e o trabalho" (Engel, 1999). Também Franco da Rocha, diretor do Juqueri, defenderia em 1904 tese semelhante, estabelecendo correlações entre "loucura moral e radicalismo revolucionário". Pode-se imaginar o temor de Lima, assim como a insistência em calar sobre suas simpatias pelo anarquismo, consideradas naquele local sinal de degenerescência intelectual. Esse é, portanto, e também, um diálogo de surdos, com o paciente buscando omitir dados de sua vida pregressa e atual, e o atendente buscando criar ambiente amistoso e que incitaria o interno "a falar".

Os inquéritos de entrada continuavam com os exames de "sensibilidade e motilidade", que no caso de Lima mostram-se "na íntegra". Já o exame de "reflexos" deixou a desejar "com as pupilas reagindo só lentamente à luz". Esse deveria ser o efeito da bebida que castigava Lima há alguns dias e que fizera com que fosse internado, delirando, depois de ter estado a vagar pelas ruas do centro do Rio. O álcool já acompanhava a vida de Lima Barreto faz tempo. No diário do ano de 1910, ele menciona a sua "mania de suicídio" e a frequência do álcool: "Só o Álcool me dá prazer e me tenta... Oh! Meu Deus! Onde irei parar?”. Nesse ano, Lima mostrava-se claramente deprimido e em seu diário, no dia 20 de abril de 1914, anotou:

O maior desalento me invade. Tenho sinistros pensamentos. Ponho-me a beber, paro. Voltam eles e também um tédio de minha vida doméstica, do meu viver cotidiano e bebo. Uma bebedeira puxa outra e lá vem a melancolia. Que círculo vicioso. Despeço-me de um por um dos meus sonhos. Já prescindo da glória, mas não queria morrer sem uma viagem à Europa, bem sentimental e intelectual, bem vagabunda e saborosa, como a última refeição de um condenado à morte. A minha casa me aborrece. O meu 
pai delira constantemente e o seu delírio tem a ironia dos loucos de Shakespeare. Meus irmãos egoístas como eles, queriam que eu lhes desse tudo o que ganho e me curvasse à Secretaria da Guerra (Barreto, 1998: 119).

Lima fora recolhido ao Hospício Nacional dos Alienados, em carro-forte e por iniciativa de seu irmão Carlindo, que nesse momento trabalhava na polícia. O escritor, apesar de considerar que "andava atrapalhando a família", jamais perdoaria o irmão e a polícia. O conto "Como o homem chegou", ${ }^{9}$ que Lima incluiu na primeira edição de Triste fim de Policarpo Quaresma, é claramente inspirado no episódio.

A polícia da República, como toda a gente sabe, é paternal e compassiva no tratamento das pessoas humildes que dela necessitam; e sempre, quer se trate de humildes, quer de poderosos, a velha instituição cumpre religiosamente a lei. [...] Naquela manhã, tinha a delegacia um movimento desusado. Passavam-se semanas sem que houvesse uma simples prisão, uma pequena admoestação. A circunscrição era pacata e ordeira. Pobre, não havia furtos; sem comércio, não havia gatunos; sem indústria, não havia vagabundos, graças à sua extensão e aos capoeirões que lá havia; os que não tinham domicílio arranjavam-no facilmente em choças ligeiras sobre chãos de outros donos mal conhecidos.

Lima narra a monotonia reinante, para depois descrever, alusivamente, sua prisão num carro forte que sacolejava sem parar.

Prontamente deu as ordens para que fosse fornecida a seu colega a masmorra ambulante, pior do que masmorra, do que solitária, pois nessas prisões sente-se ainda a algidez da pedra, alguma coisa ainda de meiguice, de sepultura, mas ainda assim meiguice; mas, no tal carro feroz, é tudo ferro, há inexorável antipatia do ferro na cabeça, ferro nos pés, aos lados uma igaçaba de ferro em que se vem sentado, imóvel, e para a qual se entra pelo próprio pé. É blindada e quem vai nela, levado aos trancos e barrancos de seu respeitável peso e do calçamento das vias públicas, tem a impressão de que se lhe quer poupar a morte por um bombardeio de grossa artilharia para ser empalado aos olhos de um sultão [...] Essa prisão de Calistenes, blindada, chapeada, couraçada, foi posta em movimento; e saiu, abalando o calçamento, a chocalhar ferragens, a trovejar pelas ruas afora em busca de um inofensivo.

Como era bem seu costume, o escritor criticava a tudo e a todos. Nesse caso, a ironia se destina à polícia, que, sem ter o que fazer, prende os inocentes. Os paralelos autobiográficos são evidentes: Fernando morava com o pai, nos arredores da cidade, era acusado de bebedeira renitente ao lado de amigos vagabundos, assim como passava o tempo vendo estrelas. Se Lima não contava estrelas, queria mesmo era viver da sua literatura, o que para muitos não passava de sinal de ócio e preguiça. O fato é que tudo parecia aborrecê-lo: o pai, os irmãos e seu trabalho na Secretaria da Guerra. Escreve no mesmo dia 20 de abril de 1914: "O que me aborrece mais na vida é esta secretaria. [...] Não posso suportá-la. É o meu pesadelo. É a minha angústia”. Há um salto temporal no diário, exatamente nesse momento, e é no dia 13 de julho que o escritor desabafa: "Enfim, a minha situação é absolutamente desesperada, mas não me 
mato [...] Hoje tive um pavor burro. Estarei indo para a loucura?" (Barreto, 1998: 120). Novo salto e uma anotação sem data: "Estive no hospício de 18-8-14 a 13-10-1914".

Os casos de alcoolismo, como o de Lima, eram aqueles que restavam menos tempo recolhidos no hospital e o escritor não fugiria à regra. Nessa primeira vez, ficaria internado apenas dois meses, que lhe custaram, porém, muito. Vale a pena, nesse sentido, analisar o diálogo que se estabelece entre Lima e o escrevente M. Pinheiro. Escreve ele: "Todos os aparelhos (digestivo, circulatório, respiratório) parecem normais"; "o único que apresenta anomalia digna de nota é o geniturinário que apresenta uma blenorragia”, também conhecida na época como esquentamento, purgação ou gonorreia. A constatação da doença venérea representava novo sintoma de degenerescência, pois configurava "excesso" e falta de regramento, "perversão" diante de um modelo cujos limites de normalidade deveriam prever práticas sexuais circunscritas, prazer moderado e com finalidade reprodutora.

Nova entrevista foi feita em 22 de agosto de 1914, quando o paciente já deveria estar menos afetado pelos efeitos do álcool e, portanto, capaz de responder questões e "falar". Tanto que nos dados "comemorativos de família", Lima informa que "sua mãe morreu tuberculosa; o pai vivo, goza saúde e é robusto. Tem três irmãos fortes". Só depois relatou que seu "pai sofre neurastenia". O conceito teria sido introduzido por Beard, em 1867, e se referia a um "estado de exaustão nervosa", tendo como sintomas "fraqueza física e mental e um nervosismo generalizado". A síndrome era entendida como a combinação de uma incapacidade de esforço físico associada a uma perturbação grave de humor. Irritação, cefaleia, distúrbios do sono e dificuldade de adaptação social levavam à ocorrência de fobias e desconfiança generalizada.

Lima conhecia os conceitos em vigor, já que num primeiro momento omite a doença do pai, para depois denunciá-la. Deveria estar a par das teorias de hereditariedade, e temer que a doença do pai fosse estigma forte a determinar suas próprias fraquezas. Também a tuberculose era nesse contexto entendida como estigma de raças degeneradas; marca pesada num exame de observação como esse. Mas falta introduzir "os comemorativos pessoais e de moléstias": "Nada informa aos antecedentes de hereditariedade. Acusa outros no rapto de manuscritos. Acusa insônias com alucinações visuais e auditivas. Estado geral bom e boa memória. Já teve sarampo e catapora, blenorragia, que ainda sofre e cancros venéreos". Pode-se imaginar a quantidade e qualidade de situações vexatórias a que o escritor tivera que enfrentar, apenas para lidar com essa parte do questionário. Insônias e alucinações eram sem dúvida efeitos passageiros do álcool e o escritor parecia não querer associar tais síndromes a qualquer herança biológica vinda do pai ou mesmo da mãe ou de sua "origem racial". Mas o literato precisou confessar mais: que tinha gonorreia e outras lesões venéreas, que eram sinônimo de vida desregrada. 
O laudo continua com Lima Barreto se confessando "alcoolista imoderado, não fazendo questão da qualidade". Comentava-se que o escritor era visto vagando pelas ruas do Rio, embriagado, com a roupa cada vez mais puída - um único terno azul e um chapéu cada vez mais amassado - e atuando de maneira agressiva quando não inconveniente. Já era mesmo "imoderado" o seu uso do álcool. O cronista deve ter, porém, se destacado da média dos pacientes e internos, já que o escrevente redigiu que ele estava "bem orientado no tempo e meio. Memória íntegra; conhece e cita com bastante desembaraço fatos da história antiga, média, moderna e contemporânea respondendo as perguntas que lhe são feitas prontamente. Têm noções de álgebra, geometria, geografia".

Pode-se imaginar o espanto diante da erudição de Lima, que conhecia muito de história e costumava citar fatos diversos em seus contos e novelas. Tanto que, nesse inquérito, que a essas alturas começava a ganhar ares de conversa, o escrevente descreve os autores prediletos de Lima: "Bossuet, Chateaubriand 'católico elegante' [sic], Balzac, Taine, Daudet”. Lima parece mais no controle da situação tanto que o relator escreve que Lima "conhece um pouco de francês e inglês", e que faz "comentários mais ou menos acertados" sobre os escritores que cita. E conclui: "em suma é um indivíduo que tem algum conhecimento e inteligente para o meio em que vive". No elogio vem de carona o preconceito, daquele que reconhece o conhecimento alheio, mas lhe concede apenas uma certa "tolerância", diante dos mais fracos e despossuídos.

A partir daí aparece um Lima um pouco delirante, misturando problemas de trabalho com receios diante de sua "fé anarquista". Quando perguntado sobre o motivo de sua internação, alegou que teriam "lhe preparado uma assombração, com o aparecimento de fantasmas, que aliás lhe causavam muito pavor". Passou, logo, a narrar um incidente junto ao tenente Serra Pulquério, "seu amigo de pândegas", que o teria acusado de fazer panfletos contra seu trabalho. Depois de negar a necessidade da internação, o escritor afirmou que fora conduzido à polícia, "tendo antes cometido desatinos em casa, quebrando vidraças, virando cadeiras e mesas". Diz que teria sido convidado pelo comissário, que lhe teria dado domicílio, até que foi transferido para a clínica. Por isso "protesta contra o seu 'sequestro', uma vez que nada fez que o justifique". Continua seu relato afirmando que notara animosidade contra si, por parte dos companheiros de trabalho no Ministério da Guerra. Relatou ainda que temia represálias por adotar as doutrinas anarquistas. E assim vai se encerrando o depoimento, com o escrevente afirmando que Lima "apresenta-se em geral calmo, só se exaltando quando narrava os motivos que justificaram sua internação". Por fim anota: "Tem duas obras publicadas: Triste fim de Policarpo Quaresma e Memórias [sic] do escrivão Isaías Caminha".

É digno de destaque o fato de Lima Barreto oscilar entre momentos mais ou menos exaltados; mais conscientes ou mais delirantes. Mesmo em estado mais afetado, o seu trajeto anarquista deveria, naquela circunstância incomo- 
dar-lhe. Por isso, talvez, apesar de afirmar "não ser grande escritor nem ótimo pensador", deve ter terminado seu relato, se valendo de seu local na literatura, garantido por suas duas obras publicadas, que o escrivão pareceu solenemente desconhecer. A conclusão sobre a "moléstia" e seu "tratamento" é clara: alcoolismo se cura com purgativo e ópio, dois medicamentos ministrados quase indiscriminadamente para outros diagnósticos.

Mas as teorias começavam a mudar, influenciadas por novos modelos. Juliano Moreira foi diretor do Hospital de 1903 a 1930, assim como da Assistência Médica e Legal de Alienados. Seu longo estágio em asilos da França, Itália e Alemanha, entre 1895 e 1902, assim como o trabalho com tuberculose, fizeram com que contestasse as teses do mestre Nina Rodrigues. Moreira ficou conhecido como o introdutor da psiquiatria no Brasil, assim como reivindicou tratamentos especiais e locais separados para alcoólatras, epilépticos, tuberculosos e portadores de doenças contagiosas e crianças. No Hospital existiam, a essas alturas, as seguintes seções: Pinel e Calmeil, para homens; Morel e Esquirol, para mulheres. Além dessas, haviam outras especiais, dedicadas a epilépticos, leprosos, pacientes com doenças infecciosas intercorrentes, crianças e tuberculosos. Juliano Moreira cercou-se de médicos com especialidades diferentes como Gustavo Riedel, Antonio Austregésilo e Henrique Roxo, já citado. Destacou-se, ainda, ao criticar as análises que faziam correlações estritas entre mestiçagem e loucura; sobretudo com a presença de negros (Barreto, 2010c: 91). Introduzindo novos elementos para a conformação do diagnóstico do paciente alienado - clima, costumes, hábitos de higiene... - Moreira daria ao hospital um perfil diverso. Não por coincidência, em sua segunda internação e em seus diários, Lima revelaria simpatias para com Moreira e o contrário diante do encontro com Roxo, que achou prepotente.

\section{NO GABINETE DE FOTOGRAFIA DO HOSPÍCIO: UM ANÔNIMO ENTRE ANÔNIMOS}

Para além das páginas do inquérito, restaria a foto de Lima e de tantos outros internos, igualmente eternizados pelas lentes de fotógrafos que permaneceram, eles mesmos, anônimos. Prática logo associada à identificação e ao registro policial - de criminosos e doentes - , a fotografia ao mesmo tempo que transformava-se em artística, ganhava lugar como registro - das gentes, da paisagem e do cotidiano, mas também da contravenção. Se Lima já havia sido clicado em situações mais alentadoras, dessa vez a expressão revela a humilhação daquele que se vê flagrado em situação vexatória. As oscilações presentes em seu diário, as tentativas de sair do círculo vicioso da bebida e de se afastar da "herança" dos pais, parecem desmascaradas pela câmara que desnuda, e pretende se constituir como verdade final e única. 
A fotografia chegou cedo ao Brasil. Foi em maio de 1839, em plena Paris modernista, que Louis Jacques Daguerre anunciou seu novo invento, que logo se transformaria em símbolo e projeção dessa época ligeira e dada a verdades voláteis. No outro lado do hemisfério, no reino tropical brasileiro, o abade Compte, já em janeiro de 1840, publicava no Jornal do Comércio artigo sobre a introdução da técnica no Império de d. Pedro. O primeiro daguerreótipo, tirado no Rio de Janeiro - no Brasil e na América Latina - , registrava o Paço Imperial com uma tropa bem à frente. Já o monarca, dado às modas científicas, achou por bem transformar-se no primeiro soberano fotógrafo, assim como incentivar o invento. A técnica se desenvolveria; rapidamente daria conta das fragilidades iniciais e ganharia em popularidade. Na Corte, os estúdios e ateliês de fotografia inundariam a elegante rua do Ouvidor, assim como entrariam nas províncias afastadas, anunciando a multiplicação da imagem de seus orgulhosos fregueses. Começava a era "dos cartões de visita", o famoso formato que permitia a distribuição de fotos em maior quantidade e qualidade. Junto com eles surgiam os estúdios cada vez melhor equipados, que asseguravam a realização de desejos mais recônditos: alguns queriam ser eternizados tendo ao fundo os trópicos americanos; outros, os longínquos Alpes suíços. Certos fregueses optavam por apresentar-se portando casacas, joias e bengalas; outros cercavam-se de livros, esculturas, pianos e globos, quase todos falsos, feitos para não durar. Balaustradas, degraus, construções feitas de papelão... Tudo servia para dar vida às representações dessas novas elites, que viam na fotografia uma via para imortalizar seu status e posição. Foi Susan Sontag, em seu Sobre fotografia (2004), quem mostrou como desde seus primórdios a fotografia serviu à mentira: anula a ação do tempo, contorna imperfeições, embeleza o óbvio.

Mas, se são conhecidos os usos que as elites fizeram da técnica, pouco se sabe sobre a presença de negros, mulatos e mestiços - livres ou cativos - nas fotografias brasileiras. E eles estão por toda parte: ora como detalhes desfocados, ora como personagens principais. Em alguns momentos parecem envergonhados; em outros, surgem orgulhosos, dignos. Certas vezes são retratados trajando vestes grandes demais e que revelam o empréstimo das roupas por ocasião da foto; em outras ostentam instrumentos de trabalho: enxadas, caixas de engraxate e toda sorte de aparatos. De um lado estão os álbuns de família, de outro as fotos vendidas como "exóticas"; tal qual souvenir para estrangeiros. Mas há uma outra forma recorrente de representação: as fotos etnográficas feitas para servir como suporte para as teorias raciais em voga. Exemplo dos mais significativo são as fotografias da famosa "Galeria dos Condenados": ao todo 320 fotos de presos, sendo 318 homens e duas mulheres. Tiradas na Casa de Correção da Corte durante vinte anos, a partir de 1834, teriam figurado na Exposição Nacional de 1875 e depois na Feira Internacional de Londres de 1876, quando técnica e ciência pareciam estar a serviço do controle e da classificação. ${ }^{10}$ Exemplo semelhante é esse, deixado nos cadernos de 
internação do Hospício da Praia Vermelha. Rostos anônimos, evidentemente forçados a posar.

Verdadeiras câmaras de tortura, as fotografias fixavam o tempo e um tipo de artificialidade. Se tudo isso é fato, a situação ficava amplificada quando os atores eram instados a cumprir tal papel, como é o caso dos alienados. Se lá estão todos eles, unidos pelo vexame do uniforme de detento, pela situação incômoda da câmara que deveria demorar demais e pedir para que o paciente ficasse imóvel por um tempo insuportável, há também detalhes a revelar emoção e contrariedade: um olhar mais altivo, um ombro levantado, uma sobrancelha irada. Grandes peças, pequenas ciladas.

\section{LIMA E SEUS COMPANHEIROS DE HOSPÍCIO}

Em seu diário, não poucas vezes Lima se queixou das humilhações sofridas no cotidiano do hospital (a exposição pública, as cenas de nudez, duchas coletivas, quartos superlotados e fétidos), mas também de seus "colegas". Ora taciturnos, ora agressivos; por vezes calados em outros momentos loquazes; humildes ou com mania de grandeza... O fato é que Lima não se reconhecia em nenhum de seus "iguais".

O caderno do Pavilhão de Observação guarda, porém, registro "democrático" de uma série de rostos e casos, que, como Lima, podem ter lutado contra o anonimato. Em Diário do hospício, ou no romance Cemitério dos vivos, o escritor relata sua experiência junto a eles e suas tentativas, todas fracassadas, de socialização. Ao pesquisador de hoje, saltam aos olhos casos parecidos com o de Lima: os alcoolizados. Conforme queixa do diretor, um dos grandes empecilhos ao bom andamento do hospital era o número elevado de alcoólatras, que correspondiam ao primeiro lugar em número de internações. Moreira defendia inclusive a criação de asilos especiais para os "bebedores", uma vez que pediam tratamento diferenciado e tinham alta mais breve. Regulares eram os casos de alcoólatras crônicos, que vira e mexe tornavam ao local. O próprio Lima, em Cemitério dos vivos, descreve tal rotina: "De quando em quando o álcool me provocava alucinações, eu incomodava os outros, metiam-se em casas de saúde ou no Hospício, eu renascia, voltava e assim levava uma vida insegura, desgostosa e desgostando os outros" (Barreto, 2010c: 247).

E ele não estaria só, ao menos nesse sentido. Vejamos o caso de J. F., de 18 anos, solteiro e brasileiro. Aparece descrito como trabalhador e traz no seu diagnóstico a sentença: "debilidade mental e alcoolismo". Além do mais, nas "informações adicionais" diz que "na Ilha do Governador onde morava era tido como feiticeiro e por isso um padre ia frequentemente benzê-lo".

$\mathrm{Na}$ foto surge sério e bastante altivo [ver foto 1 na p. 141]; não nega o olhar que dirige à câmera. Já o funcionário destaca sua passividade: 
Apresenta-se calmo; atitude de obediência, humor tranquilo. Interrogado sobre o motivo da internação diz que foi preso sem saber porquê; tem noção de meio, não de lugar e de tempo, ideação rudimentar, associação de ideias regular, diz que na Ilha do Governador onde morava era tido como feiticeiro e por isso um padre ia frequentemente benzê-lo; atenção e percepção regular, é de ínfimo nível intelectual, é analfabeto. Confessa hábitos alcoólicos exagerados, confessa alucinações auditivas; memória deficiente; responde às nossas perguntas com calma revelando uma deficiência intelectual. Quanto ao passado mórbido individual diz ter tido catapora na infância, nega infecções venéreas, acusa uma opressão que apareceu inesperadamente e que o paciente atribui a uma queda de que foi vítima do alto de um andaime; tem delírio religioso e assume atitude mística.

Aqui temos um caso que acomoda vários marcadores sociais da diferença. Preto, J. F. era também considerado alienado, alcoólatra e feiticeiro. E nesse contexto, "delírios religiosos" eram sinônimo de sinal de degenerescência. Seu tratamento não fugiu à regra - recebeu purgativo, poção tônica e ópio. Foi logo transferido para o hospício e depois não temos mais notícias.

Outro caso de alcoolismo, mas agora envolvendo uma mulher. M. D., de 22 anos, é descrita como parda e, da mesma maneira que o escritor, é evidentemente negra. Nas "informações adicionais" aparece o seguinte comentário: "Interrogada sobre o motivo da internação diz atribuí-lo ao fato de ser julgada alienada em casa porque conversava de maneira original"; "confessa alucinações visuais, via sonhos". Interessante é que, cumprindo o mesmo ritual, o funcionário sempre termina deixando o interno "falar", mas parece não dar atenção ao que o paciente aponta como razões de seu internamento. Não se sabe o que seria uma "conversa original"; mas é revelador o verbo "confessar", que esclarece que o diálogo foi realizado sob pressão. Seu tratamento - como todos: purgativo e ópio. Nos seus "comemorativos pessoais e de moléstia" consta ter "pai falecido ignorando-se a causa mortis; mãe viva gozando saúde; tem 4 irmãos e 3 irmãs gozar da saúde, tem 2 irmãos e 2 irmãs falecidos ignorando-se a causa mortis".

Submetida ao exame de "inspeção geral" foi assim avaliada: "Compleição franzina, tem estigmas físicos de degeneração, altura regular, dentes falhos na arcada dentária superior, orelhas pequenas". Mais uma vez, mesmo que se desconhecessem quais seriam os estigmas, a degeneração foi logo atribuída à paciente M. D.. Tal forma de classificação parece funcionar como um suposto prévio - vinculado aos atavismos deterministas —, e surge portanto como "condição" mais do que "decorrência" da observação. Já nos "comemorativos pessoais e de moléstia", as conclusões correspondem ao que se nota na foto: "apresenta-se calma, atitude de desânimo, humor triste". M. D. parece sim triste, mas também sonolenta. Se foi resultado dos remédios ou da doença não há como saber. O fato é que não foram poucos os doentes que reagiram, quando podiam, à internação, acusando toda sorte de artifícios: vinganças, inimizades ou meras desconfianças [ver foto 2 na p. 141]. 
M. D., como os demais, nega sua condição de alienada, dizendo ter sido julgada dessa maneira porque "em casa conversava de maneira original". Mas o atendente parece não lhe dar ouvidos e sentencia: "não tem noção de tempo e lugar; atenção um tanto esvaída, percepção regular, ideação muito lenta; associação de ideias regular; fazia uso moderado de bebidas alcoólicas, confessa alucinações visuais, via sombras, nega alucinações auditivas". A imagem que o funcionário deixa é semelhante à que observamos: "aqui no serviço tem-se mantido calma, permanecendo triste, alimentando-se mal e dormindo ainda pior; durante o interrogatório, permaneceu com a cabeça baixa respondendo secamente às perguntas que se lhe faziam, entorpecida [...] nos primeiros dias teve crise de agitação; é de ínfimo nível intelectual". Negra, sem nível intelectual, alcoolizada, M. D. era quase que uma conclusão ambulante; alienada porque degenerada.

Mas é claro que, apesar de majoritários, os alienados não eram em sua totalidade negros (definidos muitas vezes como pardos) ou alcoolizados. $\mathrm{Na}$ mesma época em que Lima esteve internado, deu entrada I. J., de 54 anos, ferreiro e de origem italiana. Não eram poucos os italianos alienados, assim como já se mencionou que os portugueses também eram classificados frequentemente de tal forma. Se seu diagnóstico era o mesmo, alcoolismo, já as informações mostram um quadro bem distinto: "diz que veio por ter tomado a comunhão depois do almoço, diz que é um grande pecado mortal é um sacrilégio que o mata"; "contou-nos que há tempo, 1 ano aproximadamente, deflorou uma menina de 9 anos a insistência dela mesma; perguntado se se arrependia de ter praticado tal ato, ficou admirado e não se absteve de perguntar-nos se de fato era esse último o pecado, arrependendo-se". Alguns elementos se destacam: o diálogo que se estabelece, a pressão religiosa e o tratamento, sempre igual: purgativo, ópio [ver foto 3 na p. 141].

Na "inspeção geral", o médico anotou: "Compleição franzina, tem estigmas físicos de degeneração, altura regular, orelhas salientes, dentes bem-implantados, [...] tem vastas cicatrizes proveniente de uma antiga dermatose, varizes dos meros inferiores, o pé direito apresenta-se ligeiramente umas hipertrofias". Não se pode saber ao certo a que estigmas físicos estaria o escrevente se referindo. Quem sabe as hipertrofias? Isso tudo lembra o conto de Lima, "As teorias do doutor Caruru", publicado na revista Careta, em 30 de outubro de 1915; apenas um ano após a primeira internação. A história versa sobre um "sábio doutor", especialista em caracteres somáticos de degenerescência, que analisa um caso de morte de "um bêbado incorrigível, vagabundo" e conclui que o indivíduo era de fato degenerado por apresentar uma perna maior que a outra. Só depois, alertado pela faxineira, se dá conta que fora um acidente prévio que criara tal deformação.

Nos "comemorativos familiares", novos elementos comprovam os efeitos da hereditariedade, dentre eles o pai falecido de infecção tísica e uma filha 
morta pela mesma causa; todos estigmas lombrosianos. Já nos "comemorativos pessoais e de moléstia", o funcionário redigiu: "Apresenta calma, sonolento, atitude de obediência, humor calmo". Interrogado sobre o motivo da internação diz ter vindo por ter tomado a comunhão depois do almoço, diz que é um grande pecado mortal, é um sacrilégio que o mata". E conclui o escrevente:

ideação confusa e lenta, associação lenta e incerta; é de ínfimo nível intelectual; perguntando-nos a cada passo se de fato é grande pecado o ter deflorado a pequena e se é por isso que lhe está reservado o inferno, lastimando amargamente a sorte e dizendo que ele não queria, mas que a moça o instigou; confessa hábitos alcoólicos exagerados, confessa alucinações visuais; depois de termos insistido sobre o pretendido defloramento disse-nos que a menina já fora em outras ocasiões deflorada e que não foi ele o deflorador, mostra-se muito preocupado com o pecado cometido. Quanto ao passado mórbido individual diz ter tido cancros venéreos; vive em constante perturbação de espírito.

Mais uma vez, o diagnóstico repisa o que já se sabe de antemão: trata-se de paciente degenerado, com antecedentes hereditários (tísica, doenças venéreas, fanatismo religioso) a condená-lo.

Existem exemplos em que o delírio se manifestava já no inquérito da entrada. Interessante é prontuário de A. A. C., de 34 anos, classificada como branca, mas evidentemente negra. No seu diagnóstico a sentença: "psicose periódica e debilidade mental". Sua foto revela um rosto disforme, aparentando mais idade do que os 34 declarados. Mas há mais informações: "vem acompanhada de seu irmão A. A. C., inferior do 1o regimento de infantaria que informa que ser ela doente desde 18 anos em consequência de uma suspensão. Ultimamente apresenta-se mais agitada tornando-se inconveniente por provocar a todos, descompondo, agredindo este [o irmão]"; "sua fisionomia lembra o imbecil" [ver foto 4 na p. 141].

O tratamento não difere muito dos demais - purgativo, calmantes e ioduretos - mas a inspeção geral sim: "A observada é de estatura e compleição regular apresentando acentuados estigmas físicos de degeneração. Está agitada, tem língua saburrosa". Nesse caso, a alienada parece não ter colaborado, pois nos "comemorativos de família" o funcionário apenas redigiu: "Nada informa, respondendo sistematicamente a tudo: Não". Nos "comemorativos pessoais e de moléstia", fica evidente o estado da paciente: "Apresenta-se agitada, chorando como criança, não fornecendo informação alguma [...] É irrequieta opondo resistência a sua condução para a sala de exame. Quando está cansada de falar e chorar cai em abatimento, mostrando-se indiferente, obstinando a nada responder. Sua fisionomia lembra o imbecil, apresentando caracteres de degeneração".

A degeneração parece unificar a todos e transformar casos evidentemente distintos em assemelhados: raças mistas apresentam vários estigmas comuns e todos eles condenam à loucura. Mas, como vimos, a deformação pode 
vir também de "delírio religioso, político ou sexual" ou do próprio ambiente. As ideias de Freud apenas começavam a entrar no ambiente psiquiátrico brasileiro, mas a associação entre sexualidade e doença mental já era recorrente e também norteava princípios de degenerescência. O "instinto sexual perturbado" interessava aos alienistas e era considerado perversão ou anomalia grave. Casos como impotência, mas também masturbação excessiva, estupros e abusos na infância eram anotados e classificados como estigmas de loucura. Veja-se nesse sentido um exemplo de histeria, internado no hospital.

E. C. C., branca, de 37 anos, casada, portuguesa, entrou em 30 de agosto de 1902. Na sua "resenha sintomática" apresentava: "Delírio religioso. Ideias persecutórias. Alucinações visuais e auditivas. Perturbações mentais. Sensação do bolo retro. Insônia. Estado de excitação". Já nos seus "comemorativos de família" estranhava o escrivão que os "pais ainda existem, são fortes e nunca tiveram manifestação nervosas. Tem doze irmãos, sendo nove vivos, uma das suas irmãs é muito nervosa e sujeita a ataques, que pela descrição, parecem histerias; os outros são todos fortes e gozam e boa saúde". Apenas duas irmãs eram assoladas pela histeria, considerada comum entre mulheres, e sobretudo as degeneradas. Nos "comemorativos individuais" conta ela

ter sido sadia na sua infância, contraindo apenas sarampo e varíola. Desde de muito cedo que seu gênio irascível se patenteou, era muito geniosa e não podia conter-se quando se via contrariada, indispondo-se com as pessoas da casa, suas amigas o que contrariava seus pais. Na idade de quatorze anos, seu organismo foi profundamente abalado sofrendo muito devido ao atentado contra sua honra, por um seu cunhado que desejou violá-la. Guarda ainda hoje ódio a este homem a ponto de adoecer quando o vê o que muito a incomoda por ser amiga de sua irmã. Tem dez filhos, sendo oito vivos, dois mortos e um aborto. Os seus partos foram todos regulares sendo seus filhos fortes. Há três anos começaram seus sofrimentos que consistem em manifestações nervosas. Tem ataques, quando esta para aparecerem estes ela sente calor na cabeça, vontade de cantar e de correr.

Aqui temos um caso clássico de "histeria nervosa" motivada por perturbação sexual, a qual é mais clara em mulheres que desenvolvem a doença. Mas o relatório continua: "A doente que esteve por muitos dias bem agitada, acha-se hoje perfeitamente tranquila. Um pouco abatida já conversava com discernimento. Diz que se estava agitada, é porque lhe queriam tirar espírito que Deus lhe deu". Descabelada e desanimada, com uma expressão de profunda tristeza, E. C. C. parece encarar a câmara com resignação e tédio [ver foto 5 na p. 141]. Certamente, esses casos não correspondem a uma mínima parte dos internos a conviver com Lima. Além dos exemplo de alcoolismo e alienação, existiam aqueles com mania de grandeza, os sorumbáticos, os falantes, os calados, os agressivos e perigosos, os calmos e prestativos, os sifilíticos, os tuberculosos e toda uma gama de doentes enlaçados pela loucura e pelas concepções largas de degeneração e hereditariedade. 
I

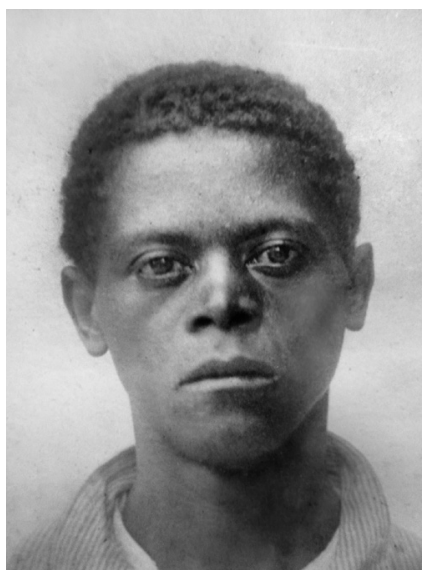

2

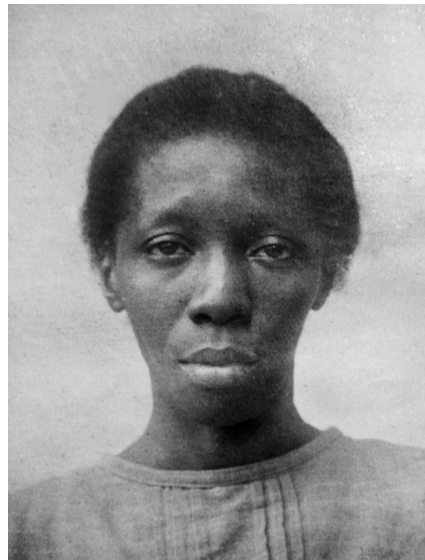

3

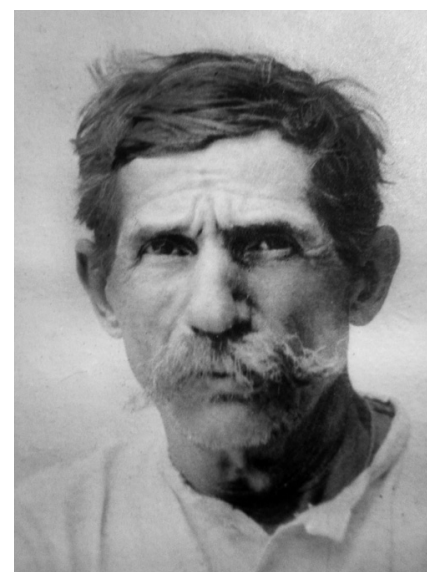

4
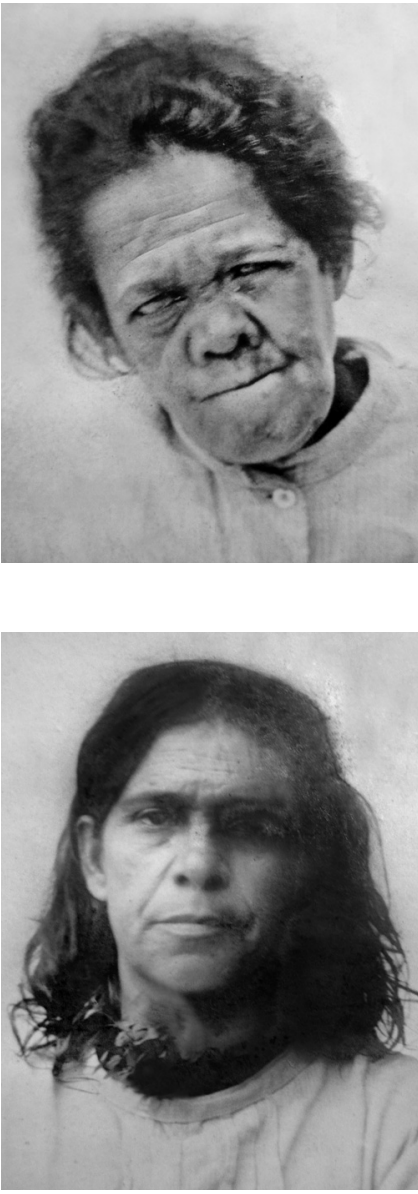

Foto 1: J.F., foto 2: M.D., foto 3: I.J.,

foto 4: A.A.C., foto 5: E.C.C.

Acervo da Biblioteca do Instituto de Psiquiatria da UFRJ, 1914. 
Mas eles correspondem, e ajudam a entender o sentimento de Lima, melhor expresso em sua obra de ficção e escondido (mal escondido) em sua personagem Vicente Mascarenhas de Cemitério dos vivos. No capítulo em que ele entra no hospício pela mão da polícia, Lima descreve o Pavilhão de Observação, assim como emite juízo sobre as práticas de aprisionamento: "A polícia, não sei como e porquê, adquiriu a mania de generalizações e as mais infantis. Suspeita de todo o sujeito estrangeiro com nome arrevessado, assim os russos, polacos, romaicos são para eles forçosamente caftens; todo cidadão de cor há de ser por força um malandro, e todos os loucos hão de ser por força furiosos e só transportáveis em carros blindados" (Barreto, 2010c: 177-178). O pior é que, como conclui Lima, "o destino me nivelara. Esqueci-me de minha instrução, da minha educação, para não demonstrar com uma inútil insubordinação [...] Não reclamei, não reclamo, não reclamarei; conto unicamente" (Barreto, 2010c: 183-184).

Tomar parte desse grupo era como viver "o espetáculo da loucura", comungar do "desatino dos loucos", ou reconhecer que no hospital "tudo é negro", por conta da "pigmentação negra de uma grande parte dos doentes... Negro é a cor mais cortante, mais impressionante...". Como conclui ele: esses eram "meus tristes companheiros de isolamento e de segregação social" (Barreto, 2010c: 203, 210, 211, 228).

\section{PARA TERMINAR OU COMEÇAR: "ANDEI PORCO, IMUNDO"}

Não há espécies, não há raças de loucos; há loucos e só.

(Barreto, 2010c: 67)

Lima Barreto teve alta "a pedido" em 13 de outubro de 1914. Mas o círculo vicioso do álcool, dos delírios, das bagunças e das internações não pararia por aí. Em 25 de dezembro seria mais uma vez recolhido. Nova internação dar-se-ia entre dezembro de 1919 e fevereiro de 1920. Outra vez durante os festejos de Natal. Sua imagem é, porém, distinta da primeira. Resignado, ou buscando dessa vez permanecer anônimo (conforme declarou em entrevista concedida no hospício), Lima é outro na ficha.

Dessa vez, o funcionário o caracteriza como pardo (e não branco); o que só indica como no país a determinação a cor é sujeita a muitas variações e condicionantes. Lima pode ter alterado a sua definição, ou a definição foi externa e, nesse caso, o escrivão anotou uma coloração mais escura; indefinida, como são os pardos: quase coringas da classificação. Quem sabe, por fim, nessa versão tão brasileira do racismo, em que se embranquece ou escurece dependendo da situação social, Lima tenha ficado "evidentemente" negro, ou melhor, pardo. Sua fisionomia, dessa vez, é conturbada e triste: cabeça deitada 
para o lado e expressão menos desafiante que a anterior. Parece vencido diante da evidência da doença, como se seu corpo desmentisse convicções profundas e contrárias às teorias deterministas sociais. Afinal, ainda em 1903, em seu diário apresentava atitude irônica e crítica com relação à ciência, dizendo que ela não passava de "um ponto de vista sobre as cousas" (Barreto, 1998: 16). No dia 26 de dezembro de 1904 desafiaria: "Porque o que é verdade na raça branca, não é extensivo ao resto, eu, mulato ou negro como queiram estou condenado a ser sempre contínuo... Quando me julgo - nada valho; quando me comparo, sou grande. Enorme consolo" (Barreto, 1998: 27).

Lima encontrava-se agora na Seção Calmeil do Hospital e, na "Anamenese", o relator, depois de desculpar-se por se encontrar de licença quando o paciente fora internado com diagnóstico de alcoolismo, anota as seguintes informações. "O inspetor dessa Seção conheceu seu pai, que era administrador das colônias de Alienados da Ilha do Governador, São Bento e Conde Mesquita, ambas criadas em 1890. Informa que este senhor fazia uso excessivo de bebidas alcoólicas, apresentando humor irascível e taciturno. Consta-nos ainda que o progenitor do observado se acha agora em avançado estado de demência". Como se vê, nessa segunda vez, o escrevente não se restringiu às informações dadas por Lima. De posse de dados externos, faz alusões sobre à carga de hereditariedade negativa. Interessante, porém, é que o segundo parágrafo desmente o primeiro com observações também retiradas de fora daquele contexto, mas atestando a importância do paciente como escritor: "O observador goza nos meios literários da reputação de um escritor talentoso e forte, cheio de mordacidade. Aliás, alguns de seus trabalhos evidenciam esses méritos de escritor. Parece que nas palestras de café é o observado muito querido por seus ditos chistosos e picantes". Paradoxal como anamenese, o primeiro parágrafo condena, enquanto que o segundo concede.

Os diários confirmam o estado do escritor, nesse meio tempo. Em 3 de junho de 1917 escreve que havia passado "o mês entregue à bebida". Em 5 de setembro, afirma: "de há muito sabia que não podia beber cachaça. Ela me abala, combale, abate todo o organismo desde os intestinos até a enervação... No dia 30 de agosto eu ia a cidade, quando me senti mal. Tinha levado todo o mês a beber, sobretudo parati. Bebedeira sobre bebedeira, declarada ou não [...] Andei porco, imundo [...] Se não deixar de beber cachaça, não tenho vergonha. Queira Deus que deixe". A situação era declinante quando Lima é aposentado pelo decreto de 26 de dezembro de 1918, e registra o fato no diário. A partir daí começam seus Diários do hospício, cuja cronologia data justamente de 1919, quando Lima afirma ter estado "no Hospital Central do Exército de 4 de novembro de 1918, a 5 de janeiro de 1919". ${ }^{11}$

De internação em internação o escritor luta entre afirmar sua identidade combalida de intelectual, de um lado, e o estigma da loucura, de outro. Indefeso para combater de frente as armas do questionário, Lima omite, se 


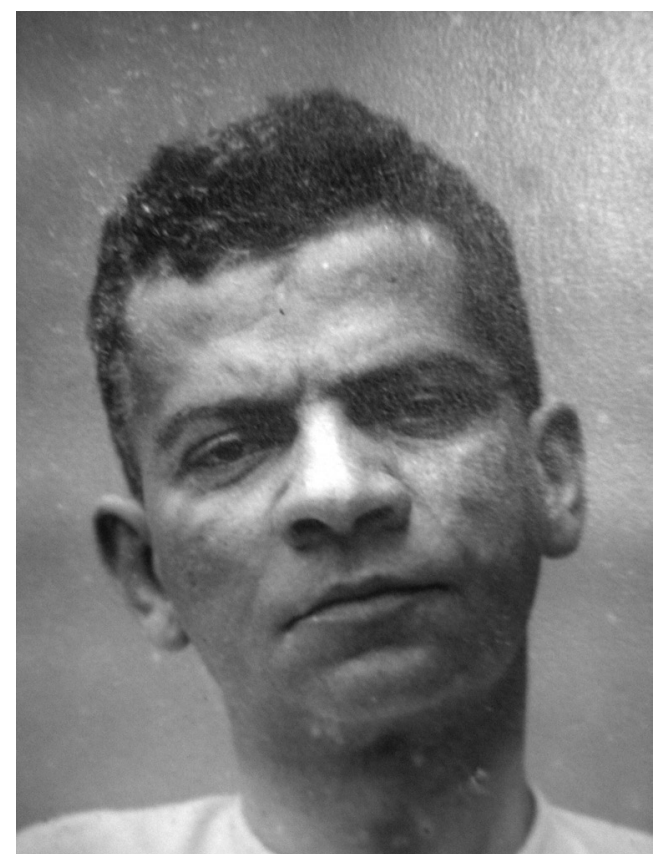

esquiva, não reage. Já fora do Hospital, e respaldado pelo terreno seguro da ficção, coloca na boca do seu personagem a reflexão que calou durante sua estada no hospício. Critica a política de "antecedentes" e a ideia de que a origem dos pacientes é sempre reveladora de sua "herança de taras ancestrais"; nega a autoridade e o orgulho do médico que "despreza as observações dos leigos e exerce sua profissão nesse "vago e nebuloso céu da loucura humana". Num crescente, admite ser um "náufrago da sociedade", um "rebotalho", "um doente indigente, "pária social", para quem a constituição pouco se endereça (Barreto, 2010c: 243-245).

Nessa hora parecem pouco lhe valer seus conhecimentos; as leituras sobre loucura de Maudsley (mesmo livro citado por Euclides da Cunha em Os Sertões) ou a Recordação da casa dos mortos de Dostoiévski, outro autor de predileção. Na crônica chamada "Da minha cela", publicada em ABC, de 30 de novembro de 1918, portanto entre uma e outra internação, lembra, com um misto de ironia e sofrimento, das suas "mensurações": "Sofri também mensurações antropométricas e tive como resultado delas um pequeno desgosto, Sou branquicéfalo". Tal termo referia-se aos indivíduos que tinham o crânio alongado e de forma ovoide, e era com frequência associada aos tipos inferiores. Era claro que, nesse texto, a citação surgia como piada. Mas sabemos também que a graça da piada está no conjunto de alusões que ela apresenta ou esconde. ${ }^{12}$ Lima negava mas dialogava, dialogicamente, com as classificações que sofria. No entanto, igualmente as temia. 
Na entrevista que concedeu para o jornal A Folha, de 31 de janeiro de 1920, quando ainda estava internado, racionaliza a sua reação mais resignada; tudo na conta do livro que estava por escrever. Disse que evitou ser reconhecido, como escritor, pois queria evitar "o pistolão". Além disso: queria "passar desapercebido, para observar melhor". Difícil dizer quem observava a quem nessa situação. Todos a todos, ou ninguém a ninguém.

Lilia Moritz Schwarcz é formada em história e antropologia. É professora titular no Departamento de Antropologia da Universidade de São Paulo (USP) e Global Professor pela Universidade de Princeton. Trabalha com temas relativos ao período do Império e da Primeira República, com atenção à questão racial no Brasil e a marcadores sociais da diferença de uma maneira geral. É autora, entre outros, de Retrato em branco e negro (1987), O espetáculo das raças (1993), As barbas do Imperador: d. Pedro II, um monarca nos trópicos (2004), A longa viagem da biblioteca dos reis (2002) e O sol do Brasil: Nicolas-Antoine Taunay e as desventuras dos artistas franceses na corte de d. João (2008). Coordenou, entre outros, o volume 4 da História da Vida Privada no Brasil: contrastes da intimidade contemporânea (1998) e, com André Botelho, Um enigma chamado Brasil (2009). Foi curadora das exposições: Virando vinte: política, cultura e imaginário em São Paulo, no final do século XIX (1994-1995), Navio Negreiro: cotidiano, castigo e rebelião escrava (1994-1998), A longa viagem da biblioteca dos reis (20032004), Nicolas Taunay: uma leitura dos trópicos (2008). Foi professora visitante nas Universidades de Oxford, Leiden, Brown, Columbia e Princeton. Faz parte do Comitê Brasileiro da Universidade de Harvard. 


\section{NOTAS}

* Agradeço a Lúcia Garcia e Pedro Galdino por inúmeras informações para esse artigo.

1 É o próprio Lima Barreto que em seu Diário do hospício descreve a vista que tinha lá dentro do hospital e afirma: "Olho a baía de Botafogo, cheio de tristeza... Tudo é triste” (2010c: 92).

2 Pioneira nesse sentido é a Escola Tropical Baiana, liderada por Nina Rodrigues, que advogava exatamente esse tipo de modelo. Para uma leitura mais aprofundada, ver, entre outros, Corrêa (1998) e Schwarcz (1993).

3 Há uma coincidência importante a anotar. No começo de 1902, houve um escândalo noticiado pelos jornais, quando o almoxarife do Hospital Nacional de Alienados, Oscar Adolpho da Costa Braga, transformou-se no centro das denúncias sobre a precariedade de funcionamento das instituições cariocas. O Jornal do Comércio de 30 de janeiro de 1902 mencionava o convívio entre crianças e adultos. A Gazeta de Comércio acusava algumas irregularidades no uso da verba pública. Sabe-se que João Henriques deu os primeiros sinais de loucura por causa de umas contas que não fechavam. Resta saber se teve acesso a essas notícias.

4 Ver, dentre outros, Carrara (1998), Costa (1979), Cunha (1990), Foucault $(1978,1980)$, Engel $(1999,2001)$, Machado (1978) e Maio \& Santos (1996).

5 Essa tradução bem como o trecho da obra de Bahkthin foram retirados da dissertação de Ricardo Teperman (2010), a quem agradeço.

6 Papéis pessoais de João Henriques de Lima Barreto. Relatórios, memorandos e cartas ao Serviço de Assistência Médico-Legal da Colônia de Alienados, pertencentes a João Henriques de Lima Barreto. 26 docs. 20/01/1891-28/05/1898. Biblioteca Nacional. Seção de Manuscritos I-6, 33, 875.

7 Em Schwarcz (2011), desenvolvo com mais vagar análise dessa obra. Recomendo, sobretudo, a leitura da edição histórica de Triste fim de Policarpo Quaresma, coordenada por Antonio Houaiss e Carmem Lúcia Negreiros (Barreto, 1997).

8 Francisco de Assis Barbosa (2002), no "Apêndice" de sua famosa biografia sobre Lima Barreto, reproduz tal documento, na íntegra.

9 Datado de 18 de outubro 1914, foi publicado originalmente na primeira edição de Triste fim de Policarpo Quaresma 
(Barreto, 1915). Na Divisão de Manuscritos da Fundação Biblioteca Nacional (BN/Mss I-6, 35, 912) há o original manuscrito intitulado "Como o 'Homem' chegou de Manaus".

10 Sobre esse tema, ver o excelente trabalho de Sandra Koutsoukos (2010).

11 Não temos como objetivo nesse artigo aprofundar análise do Diário do hospício e muito menos do romance Cemitério dos vivos, o qual guarda aberto diálogo com o primeiro, de maneira que ficção e não ficção se misturam. Estamos elaborando um artigo para o livro sobre autobiografias (coordenado por Sergio Miceli e Carlos Altamirano), em que nos deteremos nessas duas obras.

12 Ver nesse sentido Clifford Geertz (1979) e Robert Darnton (1986).

\section{REFERÊNCIAS BIBLIOGRÁFICAS:}

Bakhtin, Mikhail. A cultura popular na Idade Média e no Renascimento. São Paulo: Hucitec, 1987.

. La poetique de Dostoieuski. Paris: Edition du Seuil, 1970.

Barbosa, Francisco de Assis. A vida de Lima Barreto. Rio de Janeiro: José Olympio, 2002.

Barreto, Lima. Como o homem chegou. In: Triste fim de Policarpo Quaresma. Rio de Janeiro: Typ. Revista dos Tribunais, 1915, p. 333-352.

. Contos completos de Lima Barreto. Schwarcz, Lilia Moritz (org.). São Paulo: Companhia das Letras, 2010a.

. Recordações do escrivão Isaías Caminha. São Paulo: Penguin/Companhia das Letras, 2010b.

. Diário do hospício. São Paulo: Planeta, 1993.

. Diário do hospício e o cemitério dos vivos. Massi, Augusto \& Marcondes de Moura, Murilo (orgs.). São Paulo: Cosac \& Naify, 2010c.

. Triste fim de Policarpo Quaresma. Houaiss, Antonio \& Negreiros, Carmem Lúcia (orgs.). Madrid, Paris, México, Buenos Aires, São Paulo, Lima, Guatemala, San José da Costa Rica, Santiago de Chile: AALLCA XX/Coleção Archivos, 1997.

. Um longo sonho de futuro: diários, cartas, entrevistas e confissões dispersas. Rio de Janeiro: Graphia, 1998. 
Carrara, Sergio L. Crime e loucura: o aparecimento do manicômio judiciário na passagem do século. Rio de Janeiro: Eduerj/ Edusp, 1998.

Castel, Robert. A ordem psiquiátrica: a idade de ouro do alienismo. Rio de Janeiro: Graal, 1978.

Chalhoub, Sidney. Cidade febril: cortiços e epidemia na corte imperial. São Paulo: Companhia das Letras, 1996.

Corrêa, Mariza. As ilusões da liberdade: a escola Nina Rodrigues e a antropologia no Brasil. Bragança Paulista/São Paulo: Edusf/Fapesp, 1998.

Costa, Jurandir Freire. Ordem médica e norma familiar. Rio de Janeiro: Graal, 1979.

Cunha, Maria Clementina. Cidadela da ordem: a doença mental na República. São Paulo: Brasiliense, 1990.

Darnton, Robert. O grande massacre de gatos e outros episódios da história cultural francesa. Rio de Janeiro: Graal, 1986.

Engel, Magali. As fronteiras da "anormalidade": psiquiatria e controle social. História, ciências, saúde: Manguinhos, 1999, 5/3, p. 547-563.

Os delírios da razão. Rio de Janeiro: Ed. Fiocruz, 2001.

Foucault, Michel. História da loucura na idade clássica. São Paulo: Perspectiva, 1978.

. História da sexualidade: a vontade de saber. Rio de Janeiro, Graal, 1980.

Geertz, Clifford. A interpretação das culturas. Rio de Janeiro, Zahar, 1978.

Ginzburg, Carlo. Mitos, emblemas e sinais: morfologia e história. São Paulo: Companhia das Letras, 1989.

. O inquisidor como antropólogo: uma analogia e suas implicações. In: A micro-história e outros ensaios. Lisboa/São Paulo: Difel/Bertrand, 1991, p. 203-214.

Koutsoukos, Sandra. Negros no estúdio de fotografia. Campinas, Ed. Unicamp, 2010.

Machado, Roberto et al. Danação da norma: a medicina social e a constituição da psiquiatria no Brasil. Rio de Janeiro: Graal, 1978.

Maio, Marcos Chor \& Santos, Ricardo Ventura. Raça, ciência e sociedade. Rio de Janeiro: Ed. Fiocruz, 1996. 
Prado, Antonio Arnoni. Lima Barreto: o crítico e a crise. Rio de Janeiro: Cátedra, 1976.

Schwarcz, Lilia Moritz. O espetáculo das raças: cientistas, instituições e questão racial no Brasil (1870-1930). São Paulo: Companhia das Letras, 1993.

. Um romance em notas. In: Barreto, Lima. Triste fim de Policarpo Quaresma. São Paulo: Penguin/Companhia das Letras, 2011, p. 11-55.

Sontag, Susan. Sobre fotografia. São Paulo: Companhia das Letras, 2004.

A doença como metáfora. Rio de Janeiro: Graal, 1984.

Teperman, Ricardo. Tem que ter suingue. Dissertação de Mestrado. FFLCH-Universidade de São Paulo, 2010. 


\section{Resumo:}

O presente artigo pretende analisar o contexto em que se deu a internação de Lima Barreto, em 1914, a partir de recorte singular. De um lado, cruzando diferentes documentos produzidos pelo autor à época, como contos, diários, entrevistas, crônicas e as próprias fichas de entrada na Instituição Hospitalar. De outro, a partir da comparação dos registros de pacientes internados no Hospital nesse mesmo ano. Com esse intuito, o artigo explora marcadores sociais de diferença — raça, gênero, situação social, origem - , mostrando como o uso e manipulação dos mesmos ajuda a entender os próprios discursos legados pelos internos e especialistas. Por fim, a partir da interpretação das fotos e do uso de um método dialógico, conforme exercitado por Bakhtin e Ginzburg, busca-se recuperar pistas e vestígios, assim como entender os pacientes não só como "vítimas", mas como "protagonistas" em meio a uma situação por certo desigual.

\footnotetext{
This article aims to analyze from a singular perspective the context in which Lima Barreto was admitted in hospita, in 1914. On one side, across different documents produced by the author at the time, as short stories, diaries, interviews, stories and their own entry reports into the hospital. On the other, from the comparison of records of patients admitted to the Hospital at the same year. To that end, the article explores social markers of difference - race, gender, social status, origin -showing how using and handling them helps to understand the very speeches given by internals and experts. Finally, from the interpretation of the photographs and the use of a dialogical method, as practiced by Bakhtin and Ginzburg, I seek to recover clues and traces, as well as understand the patients not only as "victims" but as "actors" in a certainly uneven situation.
}

Palavras-chave:

Lima Barreto; Loucura; Cor; Exclusão social; Primeira República.

\section{Palavras-chave:}

Lima Barreto; Madness; Color; Social exclusion; First Brazilian Republic. 